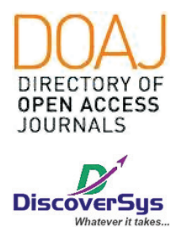

Published by DiscoverSys

\section{Gambaran faktor risiko dan tingkat risiko stroke iskemik berdasarkan stroke risk scorecard di RSUD Klungkung}

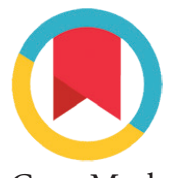

CrossMark

\author{
Ni Made Trismarani Sultradewi Kesuma, ${ }^{1 *}$ Dion Krismashogi Dharmawan, ${ }^{2}$ Heni Fatmawati ${ }^{3}$
}

\title{
ABSTRACT
}

Introduction: Indonesia is the second highest country of stroke burden after Mongolia, which are 3,382.2 / 100,000 people based on DALYs (disability-adjusted life-year). Based on the health profile of the province of Bali, the type of stroke that has high prevalence rate is ischemic stroke. Practical strategies in overcoming the burden of stroke must be focused on prevention and treatment based on risk factors. The study aims to determine the relationship between risk factors and the level of risk of ischemic stroke patients hospitalized at RSUD Klungkung Bali.

Methods: This study is observational analytic study with a cross sectional design that includes 65 patients taken from the medical records. The variables studied are age, gender, pressure blood, cholesterol levels, smoking history, body mass index (BMI), physical activity, history of diabetes, history of atrial fibrillation, and history of stroke in the family. Data analysis techniques used were univariate analysis and bivariate analysis.

Result: The most characteristics based on age group is $\geq 55$ years 64 years with an average age of $61.45 \pm 12.016$ years. Patients are dominated by men $(2,4: 1)$. The assessment of the level of risk factors in each sample using the Stroke Risk Scorecard (SRS), 51 people (78.5\%) had a high risk, 9 people (13.8\%) had moderate risk, and 5 people (7.7\%) has a low risk of ischemic stroke.

Conclusion: The chi-square statistical analysis showed a significant relationship between the risk level of ischemic stroke with body mass index, blood pressure, smoking history, history of diabetes, and cholesterol levels $(p<0,005)$.
1Program Studi Pendidikan Dokter ${ }^{2}$ Laboratorium Anatomi ${ }^{3}$ Laboratorium Histlogi Fakultas Kedokteran Universitas Jember

\section{*Korespodensi:}

Ni Made Trismarani Sultradewi Kesuma, Program Studi Pendidikan Dokter

trismarani@gmail.com

Diterima: 17-01-2019

Disetujui: 31-10-2019

Diterbitkan: 01-12-2019

Keywords: Ischemic Stroke, Risk Factors, Stroke Risk Scorecard

Cite This Article: Kesuma, N.M.T.S., Dharmawan, D.K., Fatmawati, H. 2019. Gambaran faktor risiko dan tingkat risiko stroke iskemik berdasarkan stroke risk scorecard di RSUD Klungkung. Intisari Sains Medis 10(3): 720-729. D0I: 10.15562/ism.v10i3.397

\section{ABSTRAK}

Latar Belakang: Indonesia memiliki angka beban stroke terbanyak kedua setelah Mongolia yaitu sebanyak 3.382,2/100.000 orang berdasarkan DALYs (disability-adjusted life-year). Berdasarkan profil kesehatan provinsi Bali, tipe stroke yang memiliki tingkat prevalensi yang tinggi adalah stroke iskemik. Strategi praktis dalam mengatasi beban akibat stroke harus difokuskan pada pencegahan dan penanganan berdasarkan faktor risiko. Tujuan penelitian ini adalah untuk mengetahui hubungan antara faktor-faktor risiko dengan tingkat risiko penderita stroke iskemik yang rawat inap di RSUD Klungkung Bali periode Oktober 2017 sampai dengan September 2018.

Metode: Penelitian ini merupakan penelitian analitik observasional dengan desain cross sectional. 65 Subyek penelitian yang sesuai dengan kriteria inklusi, diambil dari data rekam medis pasien stroke iskemik yang rawat inap di RSUD Klungkung. Variabel yang diteliti dalam penelitian ini yaitu usia, jenis kelamin, tekanan darah, kadar kolesterol, riwayat merokok, indeks massa tubuh (IMT), aktivitas fisik, riwayat diabetes, riwayat fibrilasi atrium, dan riwayat stroke dalam keluarga.

Hasil: Dari total 65 pasien stroke iskemik yang rawat inap di RSUD Klungkung, paling banyak berada pada kelompok usia $\geq 55$ tahun - 64 tahun dengan usia rerata 61,45 \pm 12,016 tahun. Pasien berdasarkan jenis kelamin didominasi oleh laki-laki dengan perbandingan kejadian stroke iskemik antara laki-laki dan perempuan sebesar 2,4:1. Hasil penilaian tingkat faktor risiko dengan Stroke Risk Scorecard (SRS), 51 orang $(78,5 \%)$ memiliki risiko tinggi, 9 orang $(13,8 \%)$ memiliki risiko sedang, dan 5 orang $(7,7 \%)$ memiliki risiko rendah.

Simpulan: Uji statistik chi-square menunjukkan adanya hubungan yang signifikan antara tingkat risiko stroke iskemik dengan indeks massa tubuh, tekanan darah, riwayat merokok, riwayat diabetes, dan kadar kolesterol $(p<0,005)$. 


\section{PENDAHULUAN}

Penyakit tidak menular telah membunuh 41 juta orang setiap tahun atau setara dengan $70 \%$ kematian secara global. Salah satu dari empat penyakit tidak menular utama menurut WHO adalah penyakit kardiovaskular yaitu penyakit jantung koroner dan stroke. ${ }^{1}$ Stroke menempati urutan kedua penyebab kematian terbanyak di dunia dan menyebabkan 6,2 juta kematian pada tahun $2011 .^{2}$

Selain menyumbangkan angka kematian tinggi akibat stroke, Indonesia juga memiliki angka beban stroke terbanyak kedua setelah Mongolia yaitu sebanyak 3.382,2/100.000 orang berdasarkan DALYs (disability-adjusted life-year). Prevalensi stroke di Indonesia pada tahun 2018 sebesar 10,9\% dan mengalami kenaikan sebanyak 3,9\% dalam lima tahun terakhir. ${ }^{3}$ Berdasarkan profil kesehatan provinsi Bali, tipe stroke yang memiliki tingkat prevalensi yang tinggi adalah stroke iskemik. Stroke iskemik masuk ke dalam pola 10 besar penyakit pada pasien rawat inap di RSU Provinsi Bali dalam 4 tahun berturut-turut yaitu tahun 2014-2017 dan terjadi peningkatkan kejadian stroke iskemik dari tahun 2015 ke 2016 sebesar 54\%.

Stroke menurut WHO merupakan penyakit neurologis umum yang menimbulkan tanda-tanda klinis yang berkembang sangat cepat berupa defisit neurologi fokal dan global, berlangsung selama 24 jam atau lebih dan dapat menyebabkan kematian. Stroke terjadi apabila pembuluh darah otak mengalami penyumbatan atau pecah yang mengakibatkan otak tidak mendapatkan pasokan darah yang membawa oksigen sehingga terjadi kematian sel atau jaringan otak. Pembagian stroke berdasarkan patologi anatomi dan manifestasi klinisinya yaitu stroke non-hemoragik (iskemik) dan stroke hemoragik. Stroke iskemik mencakup transient ischemic attack, stroke-in-evolution, thrombotic stroke, embolic stroke, dan stroke akibat kompresi seperti tumor, abses, dan granuloma. Stroke iskemik merupakan oklusi akut dari pembuluh darah intrakranial yang menyebabkan berkurangnya aliran darah ke wilayah otak yang disuplai. ${ }^{2,4}$

Adapun beberapa faktor risiko yang berperan menurut Farooq dan Gorelick dalam terjadinya stroke dapat dibedakan menjadi tiga kategori yaitu faktor risiko yang tidak dapat dimodifikasi, terdokumentasi dengan baik dan dapat dimodifikasi, dan kurang terdokumentasi dengan baik dan berpotensi dapat dimodifikasi. Usia, jenis kelamin, ras, berat badan saat lahir yang rendah, dan faktor-faktor genetik merupakan faktor risiko stroke yang tidak dapat dimodifikasi. Adapun faktor risiko yang terdokumentasi dengan baik dan dapat dimodifikasi adalah aktivitas fisik, hipertensi, merokok, diabetes, dislipidemia, fibrilasi atrium, dan kondisi jantung lainnya (misalnya, sick sinus syndrome, katup jantung prostetik, kardiomiopati, penyakit jantung katup, penyakit arteri koroner, dan endokarditis). Sedangkan penyakit migrain dengan aura khususnya pada wanita, sindrom metabolik, konsumsi alkohol, penyalahgunaan obat-obatan, gangguan pernafasan saat tidur, hiperhomosisteinemia, peningkatan lipoprotein merupakan faktor risiko yang kurang terdokumentasi dengan baik dan berpotensi dapat dimodifikasi. ${ }^{5}$

Pencegahan merupakan salah satu cara yang paling efektif dan efisien untuk mengurangi angka kejadian stroke. Pedoman pengendalian stroke di Indonesia menyebutkan bahwa deteksi dini faktor risiko stroke sangat berperan dalam upaya pengendalian dan menentukan prognosis stroke 5 tahun yang akan datang. The George Institute for Global Health menjelaskan bahwa strategi praktis dalam mengatasi beban akibat stroke harus difokuskan pada pencegahan dan penanganan berdasarkan faktor risiko. ${ }^{6}$

\section{METODE}

Penelitian ini merupakan penelitian analitik observasional dengan desain cross-sectional untuk untuk mengetahui hubungan antara faktor-faktor risiko dengan tingkat risiko penderita stroke iskemik yang rawat inap di RSUD Klungkung Bali. Sampel pada penelitian ini adalah pasien stroke iskemik yang terdata di rekam medis RSUD Klungkung pada bulan Oktober 2017 sampai dengan September 2018 yang memenuhi kriteria pengambilan sampel. kriteria inklusi adalah penderita stroke iskemik yang diagnosisnya telah ditegakkan oleh dokter spesialis saraf dan atau spesialis radiologi, pasien rawat inap dengan diagnosis stroke iskemik di RSUD Klungkung dalam periode 1 Oktober 2017 sampai dengan 30 September 2018, Data rekam medis yang memuat: usia, jenis kelamin, tekanan darah, kadar kolesterol, kebiasaan merokok, indeks massa tubuh (IMT), aktivitas fisik, riwayat diabetes, riwayat fibrilasi atrium, dan riwayat stroke dalam keluarga. Sedangkan kriteria ekslusi adalah rekam medis tidak lengkap yang tidak mencantumkan usia, jenis kelamin, tekanan darah, kadar kolesterol, kebiasaan merokok, indeks massa tubuh (IMT), aktivitas fisik, riwayat diabetes, riwayat fibrilasi atrium, dan riwayat stroke dalam keluarga, pasien stroke dengan riwayat aneurisma, pasien pasca stroke hemoragik, riwayat cedera kepala. 65 Sampel penelitian dipilih menggunakan metode total sampling. Variabel yang diteliti dalam penelitian ini yaitu usia, jenis kelamin, tekanan darah, kadar kolesterol, riwayat merokok, indeks massa tubuh (IMT), aktivitas fisik, riwayat diabetes, riwayat fibrilasi atrium, dan riwayat stroke dalam keluarga. 
Pengumpulan data dilakukan dengan menggunakan data sekunder melalui rekam medis pasien. Faktor risiko setiap sampel penelitian yang telah dikumpulkan, kemudian dilakukan penilaian tingkat risiko menggunakan skala skor Stroke Risk Scorecard. Penelitian ini dianalisis dengan dua tahapan yaitu analisis univariat dan analisis bivariat. Analisis univariat berupa gambaran distribusi frekuensi yang kemudian disajikan dalam bentuk presentase tabel dan gambar yang dideskripsikan dalam bentuk narasi. Analisis bivariat menggunakan uji statistik chi-square untuk melihat hubungan antara variabel. Data diolah menggunakan program SPSS 16.0. Interpretasi hasil memiliki korelasi bermakna jika $\mathrm{p}$ value $<0,05$.

\section{HASIL}

Berdasarkan Tabel 1, distribusi jenis kelamin penderita stroke iskemik yang rawat inap di RSUD Klungkung didominasi oleh laki-laki. Perbandingan kejadian stroke iskemik antara lakilaki dan perempuan dari total keseluruhan 65 orang pasien yaitu sebesar 2,4:1. Sedangkan rata-rata usia pasien stroke iskemik adalah $61,45 \pm 12,016$ dengan kelompok usia persentase tertinggi pada rentang $\geq 55$ tahun - 64 tahun sebanyak 30,8\%.

Distribusi faktor risiko dalam penelitian ini disajikan dalam Tabel 2. Faktor-faktor risiko pada penelitian ini adalah indeks massa tubuh (IMT), riwayat merokok, tekanan darah, riwayat diabetes, fibrilasi atrium, kolesterol, aktivitas fisik, dan riwayat stroke dalam keluarga. Berdasarkan hasil penilaian tingkat faktor risiko pada setiap sampel dengan menggunakan Stroke Risk Scorecard, didapatkan hasil sebanyak 51 orang $(78,5 \%)$ memiliki risiko tinggi, 9 orang $(13,8 \%)$ memiliki risiko sedang, dan 5 orang $(7,7 \%)$ memiliki risiko rendah (Tabel 3).

Hasil uji statistik menunjukkan, terdapat hubungan yang signifikan antara indeks massa tubuh dengan tingkat risiko stroke iskemik dengan nilai $p=0,0001 \quad(p<0,05)$ (Tabel 4). Hasil uji statistic antara riwayat merokok dengan tingkat risiko stroke menunjukkan nilai $p=0,031(\mathrm{p}<0,05)$ yang berarti terdapat hubungan yang signifikan antara riwayat merokok dengan tingkat risiko stroke (Tabel 5). Hasil uji statistik signifikan antara tekanan darah dengan tingkat risiko stroke iskemik menunjukkan nilai $p=0,0001(p<0,05)$ yang berarti terdapat hubungan

Tabel 1 Distribusi Jenis Kelamin dan Usia

\begin{tabular}{llcc}
\hline Variabel & & Frekuensi & Persentase \\
\hline Jenis Kelamin & Laki-laki & 46 & 70,8 \\
& Perempuan & 19 & 29,2 \\
Usia & $\leq 45$ tahun & 6 & 9,2 \\
& $>45$ tahun - 54 tahun & 13 & 20,0 \\
& $\geq 55$ tahun - 64 tahun & 20 & 30,8 \\
& $\geq 65$ tahun - 74 tahun & 16 & 24,6 \\
Total & $\geq 75$ tahun & 10 & 15,4 \\
& & 65 & $100 \%$
\end{tabular}

Tabel 2 Distribusi Faktor Risiko berdasarkan Stroke Risk Scorecard

\begin{tabular}{llcc}
\hline Variabel & & Frekuensi & Persentase \\
\hline Indeks Massa Tubuh & Obesitas & 20 & 30,8 \\
& Berat Badan Berlebih & 25 & 38,5 \\
Riwayat Merokok & Normal & 20 & 30,8 \\
& Merokok & 27 & 41,5 \\
Mencoba berhenti & 1 & 1,5 \\
& Tidak merokok & 37 & 56,9 \\
& $>140 / 90$ mmHg & 39 & 60,0 \\
Riwayat Diabetes & $120-130 / 80-89$ mmHg & 17 & 26,2 \\
& $<120 / 80$ mmHg & 9 & 13.8 \\
& Diabetes & 27 & 41,5 \\
& Pre-diabetes & 11 & 16,9 \\
& Tidak ada riwayat diabetes & 27 & 41,5 \\
\hline
\end{tabular}


Tabel 2 Continued

\begin{tabular}{llcc}
\hline Variabel & & Frekuensi & Persentase \\
\hline Fibrilasi Atrium & Ada & 21 & 32,3 \\
& Tidak tahu & 0 & 0 \\
& Tidak ada & 44 & 67,7 \\
Kadar Kolesterol & $>240 \mathrm{mg} / \mathrm{dl}$ & 14 & 21,5 \\
& $200-239 \mathrm{mg} / \mathrm{dl}$ & 22 & 33,8 \\
Aktivitas Fisik & $<200 \mathrm{mg} / \mathrm{dl}$ & 29 & 44,6 \\
& Tidak sama sekali & 26 & 40,0 \\
& $1-2$ kali perminggu & 30 & 46,2 \\
Riwayat Stroke dalam Keluarga & A-7 kali perminggu & 9 & 13,8 \\
& Tida & 10 & 15,4 \\
& Tidak tahu/ ragu-ragu & 25 & 38,5 \\
& & 30 & 46,2 \\
\hline
\end{tabular}

Tabel 3 Distribusi Tingkat Risiko Stroke Iskemik

\begin{tabular}{lcc}
\hline Tingkat Faktor Risiko & Frekuensi (n) & Persentase (\%) \\
\hline Risiko tinggi & 51 & 78,5 \\
Risiko sedang & 9 & 13,8 \\
Risiko rendah & 5 & 7,7 \\
Total & 65 & $100 \%$ \\
\hline
\end{tabular}

Tabel 4 Hubungan indeks massa tubuh dengan tingkat faktor risiko stroke iskemik

\begin{tabular}{lcccc}
\hline \multirow{2}{*}{$\begin{array}{l}\text { Indeks } \\
\text { Massa Tubuh }\end{array}$} & \multicolumn{3}{c}{ Tingkat Faktor Risiko } & P \\
\cline { 2 - 4 }$>27 \mathrm{~kg} / \mathrm{m} 2$ & $19(95 \%)$ & Risiko Sedang & Risiko Rendah & $1(5,0 \%)$ \\
$23-27 \mathrm{~kg} / \mathrm{m} 2$ & $18(72,0 \%)$ & $7(28,0 \%)$ & $0(0,0 \%)$ & 0.0001 \\
$<23 \mathrm{~kg} / \mathrm{m} 2$ & $14(70,0 \%)$ & $2(10,0 \%)$ & $4(20,0 \%)$ & \\
Jumlah & 51 & 9 & 5 \\
\hline
\end{tabular}

Tabel 5 Hubungan riwayat merokok dengan tingkat faktor risiko stroke iskemik

\begin{tabular}{lcccc}
\hline & \multicolumn{3}{c}{ Tingkat Faktor Risiko } & p \\
\cline { 2 - 4 } Kebiasaan Merokok & Risiko Tinggi & Risiko Sedang & Risiko Rendah & $0(0,0 \%)$ \\
Merokok & $25(92,6 \%)$ & $2(7,4 \%)$ & $0(0,0 \%)$ & 0.031 \\
Mencoba berhenti & $0(0,0 \%)$ & $1(100,0 \%)$ & $5(13,5 \%)$ & \\
Tidak merokok & $26(70,3 \%)$ & $6(16,2 \%)$ & 5 \\
Jumlah & 51 & 9 & \\
\hline
\end{tabular}

Tabel 6 Hubungan tekanan darah dengan tingkat faktor risiko stroke iskemik

\begin{tabular}{|c|c|c|c|c|}
\hline \multirow[b]{2}{*}{ Tekanan Darah } & \multicolumn{3}{|c|}{ Tingkat Faktor Risiko } & \multirow[b]{2}{*}{$p$} \\
\hline & Risiko Tinggi & Risiko Sedang & Risiko Rendah & \\
\hline$>140 / 90 \mathrm{mmHg}$ & $35(89,7 \%)$ & $4(10,3 \%)$ & $0(0,0 \%)$ & \\
\hline $120-130 / 80-89 \mathrm{mmHg}$ & $12(70,6 \%)$ & $5(29,4 \%)$ & $0(0,0 \%)$ & 0.0001 \\
\hline$<120 / 80 \mathrm{mmHg}$ & $4(44,4 \%)$ & $0(0,0 \%)$ & $5(55,6 \%)$ & \\
\hline Jumlah & 51 & 9 & 5 & \\
\hline
\end{tabular}


Tabel 7 Hubungan kadar kolesterol dengan tingkat faktor risiko stroke iskemik

\begin{tabular}{|c|c|c|c|c|}
\hline \multirow[b]{2}{*}{ Kadar Kolesterol } & \multicolumn{3}{|c|}{ Tingkat Faktor Risiko } & \multirow[b]{2}{*}{$p$} \\
\hline & Risiko Tinggi & Risiko Sedang & Risiko Rendah & \\
\hline$>240 \mathrm{mg} / \mathrm{dl}$ & $11(78,6 \%)$ & $2(14,3 \%)$ & $1(7,1 \%)$ & \\
\hline $200-239 \mathrm{mg} / \mathrm{dl}$ & $15(68,2 \%)$ & $7(31,8 \%)$ & $0(0,0 \%)$ & 0.0001 \\
\hline$<200 \mathrm{mg} / \mathrm{dl}$ & $25(86,2 \%)$ & $0(0,0 \%)$ & $4(13,8 \%)$ & \\
\hline Jumlah & 51 & 9 & 5 & \\
\hline
\end{tabular}

Tabel 8 Hubungan aktivitas fisik dengan tingkat faktor risiko stroke iskemik

\begin{tabular}{lcccc}
\hline & \multicolumn{3}{c}{ Tingkat Faktor Risiko } & p \\
\cline { 2 - 4 } Aktivitas Fisik & Risiko Tinggi & Risiko Sedang & Risiko Rendah & $1(3,8 \%)$ \\
\hline Tidak sama sekali & $24(92,3 \%)$ & $1(3,8 \%)$ & $2(6,7 \%)$ & 0.062 \\
1-2 kali perminggu & $21(70,0 \%)$ & $7(23,3 \%)$ & $2(22,2 \%)$ & \\
3-7 kali perminggu & $6(66,7 \%)$ & $1(11,1 \%)$ & 5 \\
Jumlah & 51 & 9 & \\
\hline
\end{tabular}

Tabel 9 Hubungan riwayat diabetes dengan tingkat faktor risiko stroke iskemik

\begin{tabular}{|c|c|c|c|c|}
\hline \multirow[b]{2}{*}{ Riwayat Diabetes } & \multicolumn{3}{|c|}{ Tingkat Faktor Risiko } & \multirow[b]{2}{*}{$p$} \\
\hline & Risiko Tinggi & Risiko Sedang & Risiko Rendah & \\
\hline Diabetes & $25(92,6 \%)$ & $1(3,7 \%)$ & $1(3,7 \%)$ & \\
\hline Pre-diabetes & $7(63,6 \%)$ & $4(36,4 \%)$ & $0(0,0 \%)$ & 0.031 \\
\hline Tidak ada riwayat diabetes & $19(70,4 \%)$ & $4(14,8 \%)$ & $4(14,8 \%)$ & \\
\hline Jumlah & 51 & 9 & 5 & \\
\hline
\end{tabular}

Tabel 10 Hubungan riwayat fibrilasi atrium dengan tingkat faktor risiko stroke iskemik

\begin{tabular}{lcccc}
\hline & \multicolumn{3}{c}{ Tingkat Faktor Risiko } & \\
\cline { 2 - 4 } Fibrilasi Atrium & Risiko Tinggi & Risiko Sedang & Risiko Rendah & $\boldsymbol{p}$ \\
\hline Ada & $16(76,2 \%)$ & $3(14,3 \%)$ & $2(9,5 \%)$ & 0.898 \\
Tidak tahu & $0(0,0 \%)$ & $0(0,0 \%)$ & $0(0,0 \%)$ & $3(7,7 \%)$ \\
Tidak ada & $35(79,5 \%)$ & $6(13,6 \%)$ & 5 \\
Jumlah & 51 & 9 & \\
\hline
\end{tabular}

\begin{tabular}{lcccc} 
Tabel 11 & \multirow{2}{*}{$\begin{array}{l}\text { Hubungan riwayat stroke dalam keluarga dengan tingkat faktor risiko stroke } \\
\text { iskemik }\end{array}$} & \multicolumn{3}{c}{ Tingkat Faktor Risiko } \\
\cline { 2 - 4 } Riwayat Stroke dalam Keluarga & Risiko Tinggi & Risiko Sedang & Risiko Rendah & $\boldsymbol{p}$ \\
\hline Ada & $8(80,0 \%)$ & $1(10,0 \%)$ & $1(10,0 \%)$ & 0.938 \\
Tidak tahu & $20(80,0 \%)$ & $5(20,0 \%)$ & $0(0,0 \%)$ & $4(13,3 \%)$ \\
Tidak ada & $23(76,7 \%)$ & $3(10,0 \%)$ & 5 \\
Jumlah & 51 & 9 & \\
\hline
\end{tabular}

yang signifikan antara tekanan darah dengan tingkat risiko stroke iskemik (Tabel 6). Hasil uji statistik menunjukkan, terdapat hubungan yang signifikan antara kadar kolesterol dengan tingkat risiko stroke iskemik dengan nilai $p=0,0001(\mathrm{p}<0,05)$ (Tabel 7).
Hasil uji statistik menunjukkan, terdapat hubungan yang signifikan antara aktivitas fisik dengan tingkat risiko stroke iskemik dengan nilai $\mathrm{p}=0,062(\mathrm{p}<0,05)$ (Tabel 8). Hasil uji statistik antara tekanan darah dengan tingkat risiko stroke 
iskemik menunjukkan nilai $p=0,031 \quad(\mathrm{p}<0,05)$, yang berarti terdapat hubungan yang signifikan antara tekanan darah dengan tingkat risiko stroke iskemik (Tabel 9). Hasil uji statistik menunjukkan, tidak terdapat hubungan yang signifikan antara riwayat fibrilasi atrium dengan tingkat risiko stroke iskemik dengan nilai $p=0,898(\mathrm{p}<0,05)$ (Tabel 10). Hasil uji statistik menunjukkan, tidak terdapat hubungan yang signifikan antara riwayat stroke dalam keluarga dengan tingkat risiko stroke iskemik dengan nilai $p=0,308(\mathrm{p}<0,05)($ Tabel 11).

\section{DISKUSI}

Pasien stroke iskemik yang dirawat inap di RSUD Klungkung pada tahun 2017-2018 lebih banyak berjenis kelamin laki-laki. Sebanyak 46 pasien $(70,8 \%)$ stroke iskemik yang dirawat inap di RSUD Klungkung pada bulan Oktober 2017 - September 2018 berjenis kelamin laki-laki dan 19 pasien $(29,2 \%)$ berjenis kelamin perempuan. Hasil ini memiliki persamaan dengan hasil penelitian yang dilakukan Kabi (2015) di Rumah Sakit Professor Dr. R. D. Kandou Manado pada Juli 2012 - Juni 2013 yang menyatakan bahwa sebanyak 55\% pasien stroke iskemik berjenis kelamin laki-laki dan 27\% berjenis kelamin perempuan. ${ }^{7}$ Hal ini mendukung penelitian Barker-Collo pada tahun 2015 yang menyatakan pria memiliki insiden stroke iskemik lebih tinggi daripada wanita. ${ }^{8}$ Penelitian yang dilakukan oleh Samai (2015) juga menyatakan bahwa secara keseluruhan angka insidensi stroke iskemik pada laki-laki 1,25 kali lipat lebih tinggi dibandingkan perempuan. ${ }^{9}$

Penelitian yang dilakukan oleh Junaidi (2004) menyebutkan bahwa laki-laki lebih rentan untuk terkena stroke iskemik sedangkan perempuan lebih cenderung untuk terkena stroke hemoragik dan memiliki risiko kematian dua kali lebih banyak dibandingkan laki-laki. ${ }^{10} \mathrm{Hal}$ ini menurut Gibson (2013) dikarenakan faktor risiko penting yang dapat dimodifikasi pada stroke iskemik adalah hipertensi, kolesterol tinggi, diabetes, merokok, obesitas, dan kurangnya aktivitas fisik. Data mengenai risiko berdasarkan jenis kelamin telah mengungkapkan laki-laki memiliki prevalensi yang lebih tinggi untuk faktor risiko seperti merokok, kolesterol tinggi, penyakit arteri koroner, dan penyakit arteri perifer. ${ }^{11}$ Penelitian menunjukkan bahwa perempuan mengalami efek neuroprotektif sebelum menopause yang berkaitan dengan hormon estrogen dan cenderung memiliki risiko stroke yang lebih rendah antara usia 40 sampai dengan 75 tahun dibandingkan dengan laki-laki, tetapi setelah 75 tahun, perempuan mengalami sekitar 50\% risiko lebih besar untuk stroke daripada laki-laki. ${ }^{9}$
Depkes RI (2009) menggolongkan usia menjadi 9 kategori yaitu masa balita (0 - 5 tahun), masa kanak-kanak (5 - 11 tahun), masa remaja awal (12 - 16 tahun), masa remaja akhir (17 - 25 tahun), masa dewasa awal (26 - 35 tahun), masa dewasa akhir (36 - 45 tahun), masa lansia awal (46 - 55 tahun), masa lansia akhir (56 - 65 tahun), dan masa manula (> 65 tahun). Sedangkan WHO (tahun), menggolongkan usia menjadi 4 kategori yaitu usia pertengahan ( 45 - 59 tahun), lanjut usia (60 - 74 tahun), usia tua (75 - 90 tahun), dan usia sangat tua (> 90 tahun). ${ }^{12}$ Berdasarkan hasil penelitian, insiden stroke meningkat seiring bertambahnya usia dan meningkat dua kali lipat setiap 10 tahun setelah usia 55 tahun. ${ }^{13}$

Hasil penelitian pada pasien yang dirawat inap di RSUD Klungkung pada Oktober 2017 sampai dengan September 2018 menunjukkan bahwa stroke iskemik lebih banyak menyerang rentang usia $\geq 55$ tahun -64 tahun. Frekuensi pasien stroke iskemik yang memiliki umur diatas 45 tahun lebih banyak dibandingkan dengan pasien dibawah 45 tahun yaitu $9,2 \%$ ( $\leq 45$ tahun), $13 \%$ ( $>45$ tahun - 54 tahun), 20\% ( $\geq 55$ tahun - 64 tahun), 16\% ( $\geq 65$ tahun -74 tahun), dan $10 \%$ ( $\geq 75$ tahun). Hal ini sejalan dengan hasil RISKESDAS tahun 2013 yang menyebutkan bahwa prevalensi stroke usia lanjut usia lebih banyak dibandingkan dengan usia muda yaitu sebesar 33\% (55 - 64 tahun), 46,1\% (65 - 74 tahun), dan $67 \%$ ( $\geq 75$ tahun). Hasil ini memberikan gambaran bahwa orang yang memiliki umur lebih tua lebih mudah untuk terkena stroke iskemik dibandingkan dengan usia muda. Hal ini berkaitan dengan teori degeneratif yang menyebabkan perubahan pada struktur dan fungsi pembuluh darah seperti diameter lumen, ketebalan dinding, kekuatan dinding dan fungsi endotel yang mendasari aterosklerosis. ${ }^{14}$

Indeks massa tubuh (IMT) dengan kategori berat badan berlebih memiliki frekuensi paling banyak yaitu sebanyak 25 pasien (38,5\%). Sedangkan kategori obesitas dan IMT normal memiliki frekuensi yang sama yaitu masing-masing sebanyak 20 pasien $(30,8 \%)$. Hal ini menunjukkan bahwa gambaran pasien stroke iskemik yang rawat inap di RSUD Klungkung memiliki berat badan berlebih dan obesitas lebih banyak daripada IMT kategori normal. Hal ini sejalan dengan penelitian Mitchell (2015), yang menunjukkan dari 1201 penderita stroke iskemik, diperoleh hasil pasien stroke iskemik yang memiliki indeks massa tubuh $>25 \mathrm{~kg} /$ $\mathrm{m}^{2}$ sebanyak $70,8 \%$ sedangkan $29,3 \%$ memiliki indeks massa tubuh $<25 \mathrm{~kg} / \mathrm{m}^{2}$. Hasil penelitian ini juga sesuai dengan penelitian yang dilakukan oleh Song pada tahun 2004 dimana terdapat hubungan yang linear antara kategori IMT terendah hingga tertinggi dengan stroke iskemik dimana risiko 
meningkat sebanyak $10 \%$ untuk peningkatan IMT $1 \mathrm{~kg} / \mathrm{m}^{2}$.

Hasil uji statistik menunjukkan adanya hubungan yang signifikan antara indeks massa tubuh dengan tingkat risiko stroke iskemik. Hal ini sejalan dengan penelitian yang dilakukan oleh Rohmah (2015) yang menyebutkan bahwa ada hubungan antara indeks massa tubuh dengan tingkat risiko stroke dengan nilai $p=0,000 \quad(p<0,01)$. sampel dengan kategori IMT obesitas memiliki risiko tinggi lebih banyak daripada sampel dengan IMT normal maupun overweight. Menurut penelitian, mekanisme yang mendasari risiko stroke iskemik pada obesitas adalah indeks massa tubuh dengan kategori berlebih dan obesitas berhubungan dengan meningkatkanya tekanan darah, kadar kolesterol dan kadar gula darah. Seseorang yang memiliki berat badan yang berlebih membuat jantung bekerja semakin keras untuk memompa darah ke seluruh tubuh yang akhirnya menyebabkan meningkatnya tekanan darah. Keadaan obesitas juga dapat meningkatkan serum trigliserida dan kadar kolesterol LDL, menurunkan kadar kolesterol HDL, dan peningkatan kadar gula dalam darah. Kolesterol LDL yang tinggi dalam darah membuat disfungsi dari endotel sebagai proses awal pembentukan aterosklerosis yang disebabkan oleh deposit kolesterol di pembuluh darah arteri. Proses aterosklerosis yang terjadi di pembuluh darah otak menyebabkan penyumbatan yang berhubungan dengan pembentukan emboli dan trombus sebagai patomekanisme dari stroke iskemik. ${ }^{15}$ Penelitian telah menunjukkan hasil yang signifikan mengenai hubungan antara kadar kolesterol dan kejadian maupun outcome pasien stroke iskemik. Beberapa penelitian menunjukkan bahwa menurunkan kadar kolesterol memiliki efek yang baik terhadap fungsi fungsional dan neurologis dan menurunkan mortalitas serta risiko kekambuhan stroke iskemik. ${ }^{16}$

Sebanyak 27 pasien $(41,5 \%)$ rawat inap stroke iskemik di RSUD Klungkung memiliki kebiasaan merokok, 1 pasien (1,5\%) sedang mencoba berhenti, dan 37 pasien $(56,9)$ tidak memiliki kebiasaan merokok. Hasil yang sama juga ditunjukkan pada penelitian yang dilakukan oleh Durga (2016) yang menunjukkan presentase pasien yang tidak merokok lebih banyak dibandingkan dengan pasien stroke iskemik yang merokok yaitu sebanyak $76,8 \%$ pasien stroke iskemik tidak merokok dan 23,2\% merokok. ${ }^{14}$ Hasil penelitian ini juga didukung oleh penemuan Marisa (2014) di RSU Dokter Soedarso Pontianak juga menunjukkan hasil dari 40 pasien, didapatkan perilaku merokok sebanyak 18 orang (45\%) dan tidak merokok sebanyak 22 orang $(22 \%) .^{17}$

Hasil analisis hubungan riwayat merokok dengan tingkat risiko stroke iskemik menunjukkan hasil yang signifikan dengan nilai $p=0,031$ $(\mathrm{p}<0,05)$. Sebanyak $25(38,5 \%)$ pasien dengan riwayat merokok memiliki risiko stroke yang tinggi berdasarkan Stroke Risk Scorecard, sedangkan di antara pasien yang tidak merokok terdapat $26(40 \%)$ pasien yang memiliki risiko tinggi. Hasil penelitian Rohmah (2015) di Jakarta juga memperoleh hasil yang sama yaitu terdapat hubungan yang signifikan antara kebiasaan merokok dan tingkat risiko stroke dengan nilai $p=0,010(\mathrm{p}<0,05)$ dan penelitian di Rumah Sakit Umum Pusat Haji Adam Malik Medan oleh Nasution (2015) dengan nilai $\mathrm{p}=0,038(\mathrm{p}<0,05) .{ }^{15} \mathrm{Hal}$ ini didukung oleh banyaknya penelitian yang meneliti hubungan antara merokok dengan kejadian stroke iskemik. Salah satunya adalah penelitian kohort yang dilakukan kepada 2530 orang oleh Xu (2013) dalam rentang waktu antara Juni 2003 sampai dengan Juli 2012 di Mongolia yang menunjukkan bahwa merokok merupakan faktor risiko independen dari stroke iskemik, dan perokok dengan detak jantung yang lebih cepat memiliki risiko tinggi stroke iskemik. Penelitian ini juga menunjukkan bahwa mengetahui riwayat merokok sangat dibutuhkan dalam memprediksi kejadian stroke. ${ }^{18}$

Karbon monoksida dan nikotin yang masuk ke dalam aliran dapat mengurangi jumlah oksigen dalam darah dan membuat jantung berdetak lebih cepat sehingga juga dapat meningkatkan tekanan darah. Tekanan darah tinggi atau hipertensi berkontribusi terhadap kerusakan pada arteri, mempermudah arteri untuk menyempit, dan secara signifikan meningkatkan risiko stroke. ${ }^{19}$ Menurut penelitian, orang-orang yang merokok memiliki kadar fibrinogen yang lebih tinggi dibandingkan dengan orang yang tidak merokok yang akhirnya mengakibatkan kepadatan darah berkurang. Selain merusak endotel pembuluh darah arteri, merokok juga dapat meningkatkan risiko penggumpalan darah dan penyempitan arteri, serta membatasi kadar oksigen dalam darah. ${ }^{19}$ Merokok juga dapat memicu terjadinya fibrilasi atrium, kondisi jantung yang terkenal sebagai salah satu faktor risiko stroke. Bahan kimia dalam rokok juga membuat trombosit lebih mungkin untuk tetap bersatu dan membentuk bekuan darah. Faktor-faktor diatas meningkatkan risiko terjadinya aterosklerosis, suatu kondisi di mana arteri menjadi menyempit dan mengeras. Aterosklerosis kemudian dapat mengurangi aliran darah dan membuat gumpalan darah lebih mudah terbentuk. Jika bekuan darah terdapat pada arteri yang mengarah ke otak, suplai darah dapat terblokir dan mengakibatkan stroke iskemik. ${ }^{19}$

Hasil penelitian menyatakan bahwa sebanyak 39 pasien $(60 \%)$ memiliki tekanan darah $>140 / 90 \mathrm{mmHg}$ yang dapat diklasifikasikan sebagai hipertensi. Sedangkan untuk 
kategori tekanan darah 120-130/80-89 $\mathrm{mmHg}$ atau pre-hipertensi terdapat sebanyak 17 pasien $(26,2 \%)$, dan kategori normal atau tekanan darah $<120 / 80 \mathrm{mmHg}$ sebanyak 9 pasien (13,8\%). Hasil penelitian menemukan adanya hubungan yang signifikan antara tekanan darah dan tingkat risiko stroke iskemik dengan nilai $p=0,0001(\mathrm{p}<0,05)$. Sebanyak $35(53,8 \%)$ pasien yang bertekanan darah $>140$ - $90 \mathrm{mmHg}$ atau masuk dalam kategori hipertensi memiliki risiko tinggi terkena stroke. Jumlah ini merupakan jumlah terbanyak diantara pasien dengan tekanan darah 120-130/80-89 mmHg dan < 120/80 mmHg yang masuk dalam risiko tinggi menurut Stroke Risk Scorecard. Hal ini didukung oleh penelitian multi centered di 22 negara tentang hubungan stroke iskemik dan hipertensi yang dilakukan oleh O’Donnell (2010) yang menemukan sebanyak 1550 dari 2337 (66\%) pasien memiliki hipertensi. ${ }^{20}$

Hipertensi secara umum diterima sebagai salah satu faktor risiko utama yang dapat dimodifikasi untuk pengembangan penyakit kardiovaskular dan kejadian serebrovaskular. Mengontrol tekanan darah pada penderita hipertensi pelu dilakukan sebgai upaya pencegahan faktor resiko. Sebuah studi cross-sectional dilakukan yang melibatkan 74 pasien yang mengunjungi klinik rawat jalan di Layanan Kesehatan Primer Tabanan III selama April hingga Mei 2017. Ada hubungan yang signifikan antara penggunaan obat antihipertensi dan variabilitas kunjungan ke kunjungan (VVV)) dalam manajemen tekanan darah hipertensi dalam pengaturan layanan kesehatan primer. $^{21}$ Sebuah penelitian menggunakan model kuasi eksperimen dengan pre-test dan post-test group design yang melibatkan 28 lansia melakukan latihan aerobik melalui latihan senam jantung sehat dengan durasi 45 menit. Ada penurunan tekanan darah sistolik $19 \mathrm{mmHg}$ (pasca latihan $(121,96 \pm 1,43 \mathrm{mmHg}$ ) dibandingkan dengan baseline $(141,35 \pm 8,76)$ (p <0,001)), diastolik sebanyak $11 \mathrm{mmHg}$ (pasca latihan (121,96 $\pm 1,43 \mathrm{mmHg})$ dibandingkan dengan baseline $(91,75 \pm 1,48)(\mathrm{p}<0,001))$, dan MAP $14 \mathrm{mmHg}$ (pasca latihan $(93,89 \pm 1,15 \mathrm{mmHg}$ ) dibandingkan dengan baseline $(108,39 \pm 1,34)$ $(\mathrm{p}<0,001))$ dalam kondisi sebelum dan setelah 60 menit latihan aerobik.22

Distribusi pasien stroke iskemik yang rawat inap di RSUD Klungkung dengan riwayat diabetes berjumlah sama dengan yang tidak memiliki riwayat diabetes yaitu sebanyak 27 orang $(41,5 \%)$ dan pasien dengan pre-diabetes sebanyak 11 orang $(16,9 \%)$. Hasil yang sama juga ditemukan pada penelitian yang dilakukan oleh Ramadany (2012) di Rumah Sakit Umum Daerah Dr. Moewardi, Surakarta bahwa dari 132 penderita stroke iskemik, $71,21 \%$ memiliki riwayat diabetes. ${ }^{23}$ Namun, hal ini berbeda dengan penelitian yang dilakukan oleh Kabi (2015), dan Alagindera (2016) yang menemukan bahwa pasien stroke iskemik yang tidak memiliki riwayat diabetes memiliki jumlah yang lebih besar dibandingkan dengan pasien yang memiliki riwayat diabetes dan pre-diabetes. ${ }^{7,14}$

Hasil analisis hubungan riwayat diabetes dengan tingkat risiko stroke iskemik menunjukkan hasil yang signifikan dengan nilai $p=0,031(\mathrm{p}<0,05)$. Pasien yang memiliki riwayat diabetes $(38,5 \%)$ masuk dalam kategori risiko tinggi lebih banyak dibandingkan dengan pasien dengan pre-diabetes $(10,8 \%)$ dan tidak ada riwayat diabetes $(29,2 \%)$. Risiko rendah didominasi oleh pasien dengan tidak ada riwayat diabetes sebanyak $4(6,2 \%)$ pasien. Ramadany (2012) juga melakukan penelitian mengenai hubungan diabetes dengan stroke iskemik dan diperoleh hasil $71,21 \%$ penderita stroke iskemik dengan diabetes. ${ }^{23}$

Menurut National Stroke Association (2018), diabetes memberikan dampak yang tidak baik pada jaringan tubuh, menyebabkan peningkatan deposit lemak atau pembekuan di bagian dalam dinding pembuluh darah dan dapat mempercepat terjadinya aterosklerosis baik pada pembuluh darah kecil maupun besar termasuk pembuluh darah yang mensuplai darah ke otak. Keadaan pembuluh darah otak yang sudah mengalami aterosklerosis sangat berisiko untuk mengalami sumbatan maupun pecahnya pembuluh darah yang mengakibatkan timbulnya serangan stroke. ${ }^{19}$

Hasil penelitian pada pasien stroke iskemik yang rawat inap di RSUD Klungkung pada Oktober 2017 sampai dengan September 2018 diperoleh hasil bahwa sebanyak 21 pasien $(32,3 \%)$ ada riwayat fibrilasi atrium, 0 pasien (0\%) tidak tahu, dan 44 pasien $(67,7 \%)$ tidak ada riwayat fibrilasi atrium. Hal ini serupa dengan hasil penelitian yang dilakukan oleh Wibisono (2012) dari 55 pasien stroke iskemik di RSUD Dr. Moewardi Surakarta yang menemukan sebanyak 11 pasien memiliki riwayat fibrilasia atrium sedangkan 44 pasien tidak memiliki riwayat. ${ }^{24}$ Hasil analisis hubungan antara riwayat fibrilasi atrium dengan tingkat risiko stroke iskemik menunjukkan nilai $\mathrm{p}=0,898$ $(\mathrm{p}<0,05)$ yang berarti tidak terdapat hubungan yang signifikan antara riwayat fibrilasi atrium dengan tingkat risiko stroke iskemik. Pasien dengan fibrilasi atrium berisiko tinggi lebih sedikit yaitu sebesar $24,6 \%$ dibandingkan pasien yang tidak memiliki riwayat fibrilasi atrium dengan angka risiko tinggi sebanyak $53,8 \%$. Hasil penelitian ini sejalan dengan penelitian Yudiyanta (2005) di RS dr. Sardjito Yogyakarta yang tidak menemukan hubungan antara fibrilasi atrium dengan terjadinya stroke iskemik. ${ }^{25}$ Namun, hasil ini berbeda dengan penelitian di RSUD dr. Moewardi dan Rumah Sakit 
Umum Pusat dr. Kariadi Semarang yang mendapatkan hasil pasien dengan fibrilasi atrium berhubungan dengan kejadian stroke iskemik. Risiko terkena stroke iskemik 8,5 kali lebih besar pada orang yang menderita fibrilasi atrium dibandingkan dengan orang yang tidak menderita fibrilasi atrium. ${ }^{24}$

Berdasarkan kadar kolesterol total, sebanyak 14 pasien $(21,5 \%)$ stroke iskemik yang rawat inap di RSUD Klungkung memiliki kadar kolesterol tinggi sebesar $>240 \mathrm{mg} / \mathrm{dl}$. Sebagian besar pasien memiliki kadar kolesterol yang normal $(<200 \mathrm{mg} / \mathrm{dl})$ yaitu sebanyak 29 orang $(44,6 \%)$ dan kadar kolesterol sedang (200-239 mg/dl) sebanyak 22 pasien $(33,8 \%)$. Kadar kolesterol memiliki hubungan yang signifikan dengan tingkat risiko stroke iskemik dengan nilai $p=0,0001(\mathrm{p}<0,05)$. Pasien dengan kadar kolesterol $>240 \mathrm{mg} / \mathrm{dl}$ berisiko tinggi lebih sedikit yaitu sebesar 24,6\% dibandingkan pasien yang memiliki kadar kolesterol $<200 \mathrm{mg} / \mathrm{dl}$ dengan angka risiko tinggi sebanyak 38,5\%. Kolesterol tinggi sebagai penyebab stroke iskemik diteliti oleh Aini (2016) yang menyebutkan adanya perbedaan yang signifikan antara kadar kolesterol pasien stroke iskemik dan stroke hemoragik. Hasil penelitian keduanya menemukan bahwa pasien dengan stroke iskemik memiliki kadar kolesterol yang lebih tinggi dibandingkan dengan pasien stroke hemoragik. Kadar kolesterol yang tinggi telah terbukti sebagai faktor independen dalam kejadian stroke iskemik. ${ }^{26}$

Aktivitas fisik yang kurang adalah salah satu faktor risiko utama terjadinya stroke dan serangan jantung, yang diawali dengan penumpukan substansi lemak dan kolesterol, yang mensuplai darah ke otot jantung dan otak yang dapat menghambat aliran darah ke otak maupun jantung. Hasil uji statistic pada penelitian ini menunjukkan nilai $\mathrm{p}=0,062$ $(\mathrm{p}<0,05)$ yang berarti tidak terdapat hubungan yang signifikan antara aktivitas fisik dengan tingkat risiko stroke iskemik. Aktivitas fisik pasien stroke iskemik yang rawat inap di RSUD Klungkung didominasi aktivitas fisik yang memiliki frekuensi kurang dari 3 kali perminggu yaitu sebanyak 30 orang $(46,2 \%)$. Aktivitas fisik yang teratur ( $>3$ kali per minggu) memiliki frekuensi paling rendah yaitu sebanyak 9 orang $(13,8 \%)$ dan 26 orang $(40,0 \%)$ tidak melakukan aktivitas fisik dan lebih memilih untuk duduk didepan televisi. Aktivitas fisik teratur cenderung dilakukan oleh pasien yang dalam usia produktif $(>45$ tahun - 54 tahun). Sedangkan untuk kategori pasien yang tidak melakukan aktivitas fisik secara regular didominasi oleh pasien lanjut usia (> 54 tahun). Hasil penelitian ini sejalan dengan penelitian yang dilakukan oleh Kristiyawati dan Hariyati (2008) yang melakukan analisis hubungan antara aktivitas fisik dengan kejadian stroke dan diperoleh hasil tidak ada hubungan yang signifikan antara aktivitas fisik dengan kejadian stroke $(\mathrm{p}=0,137$ dan $\mathrm{OR}=2,231) .{ }^{27}$
Riwayat stroke dalam keluarga pada penderita stroke iskemik yang dirawat inap di RSUD Klungkung pada Oktober 2017 sampai dengan September 2018 menunjukkan hasil paling sedikit yaitu sebesar 10 pasien $(15,4 \%)$ dibandingkan dengan pasien tanpa riwayat stroke dalam keluarga sejumlah 30 pasien $(46,2 \%)$ dari total keseluruhan pasien stroke iskemik yang diteliti. Riwayat stroke dalam keluarga diduga berhubungan kuat dengan faktor-faktor risiko stroke seperti hipertensi, diabetes, dan dislipidemia yang berada di bawah pengaruh genetic. ${ }^{28}$ Namun, pada penelitian ini hasil uji statistik menunjukkan nilai $\mathrm{p}=0,308(\mathrm{p}<0,05)$ yang berarti tidak terdapat hubungan yang signifikan antara riwayat stroke dalam keluarga dengan tingkat risiko stroke iskemik. Pasien stroke iskemik yang memiliki riwayat stroke dalam keluarga berisiko tinggi lebih sedikit yaitu sebesar 12,3\% dibandingkan pasien yang tidak memiliki riwayat stroke dalam keluarga dengan angka risiko tinggi sebanyak $35,4 \%$. Hasil yang sama juga diperoleh dari hasil penelitian di RS Margono Soekardjo Banyumas oleh Ramdani (2018) yang menyebutkan mayoritas penderita stroke $(64,4 \%)$ tidak memiliki riwayat stroke dalam keluarga. ${ }^{29}$

\section{KETERBATASAN}

Penelitian ini menggunakan data sekunder dari rekam medis RSUD Klungkung sehingga validitas data dalam penelitian ini sangat bergantung pada kualitas dan kelengkapan data rekam medis. Variabel-variabel yang diteliti dalam penelitian ini menggunakan kategori yang berpedoman pada Stroke Risk Scorecard, sehingga kategori-kategori lain yang dapat menunjang penelitian tidak dapat digunakan.

\section{SIMPULAN}

Faktor risiko yang terbukti memiliki hubungan yang signifikan dengan tingkat risiko stroke berdasarkan uji statistik adalah indeks massa tubuh, tekanan darah, riwayat merokok, riwayat diabetes, kadar kolesterol.

\section{KONFLIK KEPENTINGAN}

Penulis menyatakan tidak terdapat suatu konflik kepentingan terhadap publikasi dari artikel ini.

\section{PENDANAAN}

Penelitian ini tidak mendapatkan suatu pendanaan yang diberikan oleh pemerintah ataupun lembaga swasta lainnya. 


\section{KONTRIBUSI PENULIS}

Konsep penelitian: Ni Made Trismarani Sultradewi Kesuma, Dion Krismahogi Dharmawan, Heni Fatmawati. Pengumpulan data, input data dan pengolahan data: Ni Made Trismarani Sultradewi Kesuma. Penyusunan naskah Penelitian: Ni Made Trismarani Sultradewi Kesuma.

\section{ETHICAL CLEARANCE NUMBER}

11216/H25.1.11/KE/2018.

\section{DAFTAR PUSTAKA}

1. World Health Organizations. Noncommunicable Disease. 2017. [serial online] http://www.who.int/news-room/factsheets/detail/noncommunicable-diseases [10 September 2018].

2. Smith WS., Johnston SC., dan Hemphill JC. Cerebrovascular Disease, dalam Braunwald, E., Kasper, D. L., Hauser, S. L., Longo, D. L., Jameson, J. L., dan Loscalzo, J. (Eds.), Harrison's Principles of Internal Medicine 19 th Ed. United States of America: The McGraw-Hill Companies, Inc. 2015.

3. Balitbang Kemenkes RI. Riset Kesehatan Dasar; RISKESDAS. Jakarta: Balitbang Kemenkes RI. 2018.

4. Mardjono M., dan Sidharta P. Neurologi Klinis Dasar. Jakarta: Penerbit PT Dian Rakyat. 1989.

5. Gorelick PB., and Farooq MU. Stroke: an emphasis on guidelines. The Lancet Neurology. 2015. 14(1).

6. Cardiovascular Division \& Health Services Research Centre. Reducing the Burden of CVD in Indonesia. Newton: The George Institute for Global Health. 2017.

7. Kabi GY., Tumewah R., dan Kembuan MA. Gambaran Faktor Risiko Pada Penderita Stroke Iskemik yang dirawat Inap Neurologi RSUP Prof. Dr. R D Kandou Manado Periode Juli 2012 - Juni 2013. Jurnal e-CliniC. 2015. 3(1): 457-462.

8. Barker-Collo S., Bennett DA., Krishnamurthi RV., Parmar P., Feigin VL., Naghavi M., Forouzanfar MH., Johnson CO., Nguyen G., Mensah GA., dan Vos T. Sex Differences in Stroke Incidence, Prevalence, Mortality and Disability-Adjusted Life Years: Results from the Global Burden of Disease Study 2013. Neuroepidemiology. 2015. 45: 203-214.

9. Samai AA., dan Martin-Schild S. Sex Differences in Predictors of Ischemic Stroke: Current Perspectives. Vascular Health and Risk Management. 2015. 11: 427 .

10. Junaidi, Iskandar. Panduan Praktis Pencegahan dan Pengobatan Stroke. Jakarta: PT Bhuana Ilmu Populer. 2004.

11. Gibson CL. Cerebral Ischemic Stroke: Is Gender Important? Journal of Cerebral Blood Flow \& Metabolism. 2013.33(9): 1355-1361.

12. Departemen Kesehatan Republik Indonesia. Sistem Kesehatan Nasional Bentuk dan Cara Penyelenggaraan Pembangunan Kesehatan. Jakarta: Dirjen Pelayanan Medik. 2009.

13. Boehme AK., Esenwa C., dan Elkind MSV. Stroke Risk Factors, Genetics, and Prevention. AHA Journals. 2017. 120: 472-495.

14. Alagindera D. Gambaran Faktor Risiko Kejadian Stroke Iskemik Pada Pasien yang Dirawat Inap di Rumah Sakit Umum Pusat Haji Adam Malik Medan Periode Januari 2015 - Desember 2015. Skripsi. Medan: Fakultas Kedokteran Universitas Sumatera Utara. 2016.
15. Rohmah RM. Penilaian Tingkat Risiko dan Faktor-faktor yang Berhubungan dengan Stroke pada Masyarakat Binaan KPKM Buaran FKIK UIN Syarif Hidayatullah Tahun 2015. Skripsi. Jakarta: Fakultas Kedokteran dan Ilmu Kesehatan UIN Syarif Hidayatullah. 2015.

16. Bringeland GH., Nacu A., Waje-Andreassen U., Thomassen L., dan Naess H. U-curve Relation between Cholesterol and Prior Ischemic Stroke. Wiley Brain and Behavior. 2016

17. Marisa. Hubungan Perilaku Merokok dengan Kejadian Stroke di Bagian Saraf RSU Dokter Soedarso Pontianak Periode Juni-Juli 2012. Skripsi. Pontianak: Fakultas Kedokteran Universitas Tanjungpura. 2014

18. Xu T., Bu X., Li H., Zhang M., Wang A., Tong W., Xu T., Sun Y., dan Zhang Y. Smoking, Heart Rate, and Ischemic Stroke: A Population-Based Prospective Cohort Study Among Inner Mongolians in China. Stroke. 2013. 44(9): 2457-2461.

19. National Stroke Association. Stroke Risk Scorecard. 2018. [serial online] http://www.stroke.org/sites/default/files/ resources/StrokeScorecard_2018.pdf [23 September 2018].

20. O’Donnell MJ., Xavier D., Liu L., Zhang H., Chin SL., RaoMelacini P., Rangarajan S., Islam S., Pais P., McQueen MJ., dan Mondo C. Risk Factors for Ischemic and Intracerebral Haemorrhagic Stroke in 22 Countries (The Interstroke Study): A Case-control Study. The Lancet. 2010. 376(9735): 112-123.

21. Pertiwi GAR, Aryawangsa AAN, Prabawa IPY, Manuaba IBAP, Bhargah A, Ratni NWS, Budiana IPG. Factors associated with visit-to-visit variability of blood pressure in hypertensive patients at a Primary Health Care Service, Tabanan, Bali, Indonesia. Family Medicine and Community Health. 2018;6(1):191-199.

22. Bhargah A, Muliarta M, Prabawa IPY, Manuaba IBAP, Bhargah V. Post-Exercise Hypotension Phenomenon in Elderly after Aerobic Exercise. Journal of Global Pharma Technology. 2018; 10(6):323-327

23. Ramadany AF., Pujarini LA., dan Candrasari A. Hubungan Diabetes Melitus Dengan Kejadian Stroke Iskemik di RSUD Dr. Moewardi Surakarta Tahun 2010. Biomedika. 2013.5(2).

24. Wibisono DH. Hubungan Antara Stroke Iskemik Akibat Dislipidemia dan Lokasi Infark di RSUD Dr. Moewardi di Surakarta. Skripsi. Surakarta: Fakultas Kedokteran Universitas Muhammadiyah Surakarta. 2012.

25. Yudiyanta DP. Perbedaan Abnormalitas Elektrokardiografi Pada Pasien Stroke Semoragik dan Stroke Infark. Tesis. Yogyakarta: Universitas Gajah Mada. 2005

26. Aini AQ. Perbedaan Kadar Kolesterol Total Antara Penderita Stroke Iskemik dan Stroke Hemoragik di RSUD Dr. Moewardi. Biomedika. 2016. 8(2): 1-5.

27. Kristiyawati SP. dan Hariyati TS. Faktor Risiko Yang Berhubungan Dengan Kejadian Stroke di Rumah Sakit Panti Wilasa Citarum Semarang. Jurnal Ilmu Keperawatan dan Kebidanan. 2009. 1(1).

28. Salehi, S., Tajmiri, S., Bahonar, A. A comparative study of individual and familial situation and history of diseases in female and male patients suffering from stroke. Bali Medical Journal. 2017. 6(3): 585-589. DOI:10.15562/bmj. v6i3.651.

29. Ramdani ML. Karakteristik dan Periode Kekambuhan Stroke pada Pasien dengan Stroke Berulang di Rumah Sakit Margono Soekardjo Purwokerto Kabupaten Banyumas. Jurnal Keperawatan Muhammadiyah. 2018. 3(1).

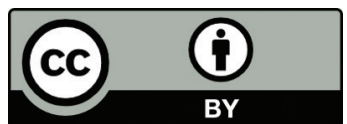

This work is licensed under a Creative Commons Attribution 